Agro Ekonomi Vol. 24/No. 1 Juni 2014

\title{
ANALISIS EFISIENSI ALOKATIF FAKTOR-FAKTOR PRODUKSI SORGUM DI KABUPATEN GUNUNGKIDUL
}

\section{Allocative Efficiency Analysis of Sorghum Production Factors in Gunungkidul District}

\author{
Sandi Budi Arta ${ }^{1)}$, Dwidjono Hadi Darwanto ${ }^{2)}$, Irham ${ }^{2)}$ \\ 1) Jurusan Sosial Ekonomi Pertanian Fakultas Pertanian Universitas Gadjah Mada \\ ${ }^{2)}$ Fakultas Pertanian Universitas Gadjah Mada
}

\begin{abstract}
This research aims to (1) determine the factors that influence the sorghum production in Gunungkidul District; (2) determine theallocative efficiency of sorghum production factors in Gunungkidul District. Number of respondents were 30 farmers chosen by purposive sampling. Analysis tools used in this research were the Cobb-Douglass Production Function and Allocative Efficiency Analysis. The result showed that the inputs such as land, seeds and organicfertilizerpositive affected to production of sorghum in Gunungkidul District. Result ofAllocative Efficiency analysis showedthat allocation ofland, seeds and organicfertilizer have not been efficient insorghum'sfarming in Gunungkidul District.
\end{abstract}

Keywords: allocative efficiency, production, sorghum

\section{INTISARI}

Penelitian ini bertujuan untuk (1) mengetahui faktor-faktor yang mempengaruhi produksi sorgum di Kabupaten Gunungkidul; (2) mengetahui efisiensi alokatif faktor-faktor produksi sorgum di Kabupaten Gunungkidul.Jumlah responden sebanyak 30 petani dengan pengambilan sampelsecara sengaja. Alat analisis yang digunakan adalah Fungsi Produksi Cobb-Douglass dan Analisis EfisiensiAlokatif. Hasil penelitian menunjukkan pemanfaatan luas lahan, benih, dan pupuk kandang berpengaruh positif terhadap produksi sorgum di Kabupaten Gunungkidul. Hasil analisis efisiensi alokatif menunjukkan pemanfaatan luas lahan, penggunaan benihdan penggunaan pupuk kandang belum efisien dalam usahatani sorgum di Kabupaten Gunungkidul.

Kata kunci: efisiensi alokatif, produksi, sorgum

\section{PENDAHULUAN}

Sorgum (Sorgum bicolor L.) merupakan tanaman serealia biji-bijian yang termasuk famili Graminaea atau rerumputan. Di Indonesia, saat ini tanaman sorgum memberi peluang untuk dikembangkan sebagai tanaman pangan, pakan dan penghasil bioetanol (bioenergi). Sebagai bahan pangan, sorgum bisa menjadi sumber pangan alternatif yang dapat dikembangkan untuk mendukung program diversifikasi dan ketahanan pangan. Sorgum biasanya dikonsumsi dalam bentuk roti, bubur, minuman, keripik dan lainnya, untuk ternak, biji sorgum juga dipakai sebagai campuran konsentrat. Daun sorgum dan ampas batang juga bisa dimanfaatkan untuk pakan ternak atau untuk dibuat kompos. Beberapa negara, seperti Amerika Serikat, India dan Cina sudah menggunakan nira dari batang sorgum sebagai bahan baku pembuatan bioetanol. Di Indonesia sorgum telah lama dikenal oleh petani khususnya di Jawa, NTB dan NTT, biasa ditanam oleh petani sebagai tanaman sela atau tumpang sari dengan tanaman lainnya. Budidaya dan pengembangan tanaman sorgum di Indonesia masih sangat terbatas, hal ini disebabkan karena kurangnya informasi tentang benih unggul, pemanfaatan sorgum dan teknologi budidayanya. Sorgum memiliki prospek yang cerah, karena lahan pertanian yang sesuai cukup luas, mampu memanfaatkan lahan tidur sehingga lebih produktif, dan tidak berkompetisi dengan tumbuhan lain karena dapat tumbuh di lahan marginal (Sukmadi, 2010).

Gandum kurang cocok, sedangkan sorgum cocok di Indonesia. Areal yang berpotensi untuk pengembangan sorgum di Indonesia sangat luas, meliputi daerah beriklim kering atau musim hujannya pendek serta tanah yang kurang subur. Daerah penghasil sorgum dengan pola pengusahaan tradisional adalah Jawa Tengah (Purwodadi, Pati, Demak, Wonogiri), Daerah Istimewa Yogyakarta (Gunungkidul, 
Kulonprogo), Jawa Timur (Lamongan, Bojonegoro, Tuban, Probolinggo), dan sebagian Nusa Tenggara Barat dan Nusa Tenggara Timur (Sirappa, 2003).

Kabupaten Gunungkidul adalah salah satu daerah penghasil sorgum di Daerah Istimewa Yogyakarta. Sorgum dapat dijadikan sebagai bahan pangan alternatif selain padi, jagung, gandum dan sagu. Sorgum memiliki prospek yang cerah, karena lahan pertanian yang sesuai cukup luas, mampu memanfaatkan lahan tidur sehingga lebih produktif, dan tidak berkompetisi dengan tumbuhan lain karena dapat tumbuh di lahan marginal,akan tetapi produksi yang ada saat ini masih tergolong rendah. Produktivitas sorgum di Kabupaten Gunungkidul berdasarkan data dari BPS (Gunungkidul Dalam Angka 2012) hanya sebesar $314 \mathrm{~kg} / \mathrm{ha}$ masih sangat rendah karena sorgum mampu berproduksi hingga lebih dari 5 ton/ha.

Permasalahan produksi sorgum yang masih rendah di Kabupaten Gunungkidul diduga berkaitan erat dengan persoalan efisiensi penggunaan input, alokasi penggunaan input diduga masih belum optimal. Salah satu indikator dari efisiensi adalah jika sejumlah output tertentu dapat dihasilkan dengan menggunakan sejumlah kombinasi input yang lebih sedikit atau kombinasi input-input tertentu dapat meminimumkan biaya produksi tanpa mengurangi output yang dihasilkan. Efisiensi alokatif dapat diformulasikan setelah mengetahui faktor-faktor yang mempengaruhi produksi.

Faktor-faktor produksi yang mempengaruhi produksi sorgum dapat diketahui dengan estimasi terhadap input-input yang digunakan oleh petani dalam fungsi produksi.Fungsi produksi dapat menjelaskan penggunaan input-input yang mempengaruhi produksi, input yang diduga mempengaruhi produksi diantaranya pemanfaatan luas lahan, penggunaan benih, penggunaan pupuk dan penggunaan tenaga kerja. Efisiensi alokatif dapat diketahui dari penggunaan input yang secara signifikan mempengaruhi produksi sorgum, efisiensi alokatif akan tercapai ketika nilai produk marginal dari penggunaan input sama dengan harga input tesebut.
Penelitian ini bertujuan untuk mengetahui faktor-faktor yang mempengaruhi produksi sorgum di Kabupaten Gunugkidul; mengetahui efisiensi alokatif faktor-faktor produksi sorgum di Kabupaten Gunugkidul.

\section{LANDASAN TEORI}

\section{Teori Produksi}

Fungsi produksi untuk setiap komoditi adalah suatu persamaan, Tabel, atau grafik yang menunjukkan jumlah (maksimum) komoditi yang dapat diproduksi per unit waktu bagi setiap kombinasi input alternatif, bila menggunakan teknik produksi terbaik yang tersedia. Suatu fungsi produksi pertanian yang sederhana diperoleh dengan menggunakan berbagai alternatif jumlah tenaga kerja per unit waktu untuk mrnggarap sebidang tanah yang tetap dan mencatat alternatif output yang dihasilkan per unit waktu. Produk rata-rata tenaga kerja (average product of labor $=\mathrm{AP}$ ) didefinisikan sebagai produk total (TP) dibagi jumlah unit tenaga kerja yang digunakan. Produk marginal tenaga kerja (marginal product of labor $=\mathrm{MP}$ ) ditentukan oleh perubahan produk total( TP) per unit perubahan jumlah tenaga kerja yang digunakan (Salvatore, 2007).

Fungsi produksi merupakan suatu fungsi yang menunjukkan hubungan teknis antara hasil produksi fisik (output) dengan faktor-faktor produksi (input). Dikenal juga dengan istilah faktor relationship (FR). Dalam bentuk matematika sederhana, hubungan ini dituliskan sebagai berikut:

$$
\mathrm{Y}=\mathrm{f}\left(\mathrm{x}_{1}, \mathrm{x}_{2}, \mathrm{x}_{3}, \ldots \ldots . . \mathrm{x}_{\mathrm{n}}\right)
$$

Keterangan :

$\mathrm{Y}=$ Hasil produksi fisik

$\mathrm{X}_{1}, \ldots \mathrm{X}_{\mathrm{n}}=$ Faktor-faktor produksi

Produksi fisik dihasilkan oleh bekerjanya beberapa faktor produksi sekaligus, yaitu tanah, modal, dan tenaga kerja, untuk menggambarkan dan/atau menganalisis peranan masing-masing faktor produksi terhadap produksi fisik, dari sejumlah faktor produksi yang digunakan, salah satu faktor produksi dianggap sebagai variabel (berubah-ubah), sementara faktor produksi lainnya diasumsikan konstan (tidak berubah). Hubungan fungsional tersebut berlaku untuk 
semua faktor produksi, yaitu tanah, modal, dan tenaga kerja, termasuk faktor produksi keempat, yaitu manajemen yang berfungsi mengkoordinir ketiga faktor produksi yang lain.

\section{Model Fungsi Cobb Douglas}

Fungsi produksi Cobb Douglas dikenal juga dengan power function. Persamaan fungsi Cobb Douglas adalah sebagai berikut:

$$
\mathrm{Y}=\mathrm{aX}_{1}{ }^{\mathrm{b} 1} \mathrm{X}_{2}{ }^{\mathrm{b} 2} \mathrm{X}_{3}{ }^{\mathrm{b} 3} \ldots \ldots \mathrm{X}_{\mathrm{n}}^{\mathrm{bn}} \mathrm{e}
$$

Keterangan:

Y : output produk (variabel dependen)

$\mathrm{X}_{1}, \ldots \mathrm{X}_{\mathrm{n}}$ : input produksi (variabel independen)

a $\quad$ : konstanta (intersep)

$b_{1}, \ldots b_{n} \quad:$ koefisien regresi (elastisitas produksi)

Keunggulan fungsi Cobb Douglas ini antara lain

a. koefisien koefisien regresi (b1, b2, ......bn) menggambarkan tingkat elastisitas input tersebut

b. konstanta (a) merupakan indeks efisiensi produksi (Pratisto, 2004).

\section{Teori Efisiensi Alokatif}

Efisiensi penggunaan input dapat terjadi ketika petani mampu membuat suatu upaya agar nilai produk marginal (NPM) untuk suatu input sama dengan harga input tersebut, dalam bentuk matematis:

$$
\mathrm{NPMx}=\mathrm{Px} \text { atau NPMx/Px }=1 .
$$

Ada 2 hal yang perlu dipertimbangkan ketika analisis efisiensi akan dilakukan, antara lain:

a. Tingkat transformasi antara input dan output dalam fungsi produksi.

b. Perbandingan antara harga input dan output sebagai upaya untuk mencapai indikator efisiensi (Soekartawi 1990).

Efisiensi yang demikian disebut dengan efisiensi harga atau allocative efficiency atau disebut juga sebagai price efficiency. Jika keadaan yang terjadi adalah:

1. $\mathrm{NPMx} / \mathrm{Px}=1$ maka penggunaan input $\mathrm{x}$ sudah efisien.

2. NPMx/Px $<1$ maka penggunaan input $\mathrm{x}$ tidak efisien dan perlu mengurangi penggunaan input.
3. $\mathrm{NPMx} / \mathrm{Px}>1$ maka penggunaan input $\mathrm{x}$ belum efisien dan perlu menambah penggunaan input.

\section{METODE PENELITIAN}

Penelitian ini dilakukan dengan menggunakan metode analisis deskriptif, yaitu yaitu metode yang dimaksudkan untuk mengangkat fakta keadaan, variabel, dan fenomena-fenomena yang terjadi saat sekarang, data dikumpulkan kemudian dianalisis secara sistemik sehingga lebih mudah dipahami dan disimpulkan (Wirartha, 2006).

Penelitian ini dilakukan di Kabupaten Gunungkidul. Pemilihan lokasi secara purposive didasarkan pada pertimbangan bahwa Kabupaten Gunungkidul merupakan daerah penghasil sorgum. Penentuan sampel petani dipilih secara sengajadengan mengambil sejumlah 30 orang petani di daerah penghasil sorgum yang telah ditentukan yaitu petani yang telah memproduksi sorgum dalam bentuk biji.

\section{Analisis Regresi}

Model analisis yang digunakan untuk mengetahui faktor-faktor yang mempengaruhi produksi sorgum adalah model analisis regresi linier berganda fungsi Cobb-Douglas sebagai berikut :

$$
\begin{aligned}
\operatorname{Ln} Y= & \ln a+b_{1} \ln X_{1}+b_{2} \ln X_{2}+b_{3} \ln X_{3}+ \\
& b_{4} \ln X_{4}+b_{5} \ln X_{5}
\end{aligned}
$$

Keterangan :

$\mathrm{Y}=$ Produksi sorgum $(\mathrm{kg})$

$\mathrm{X}_{1}=$ Luas lahan (ha)

$\mathrm{X}_{2}=$ Jumlah benih $(\mathrm{kg})$

$\mathrm{X}_{3}=$ Pupuk kandang $(\mathrm{kg})$

$\mathrm{X}_{4}=$ Pupuk urea $(\mathrm{kg})$

$\mathrm{X}_{5}=$ Tenaga kerja (HKO)

Menurut Gujarati (2006) untuk menguji hipotesis yang menggunakan OLS maka harus memperhatikan nilai adjusted $\mathrm{R}^{2}$, uji $\mathrm{F}$, dan uji t. Adjusted $\mathrm{R}^{2}$ merupakan koefisien yang menyatakan presentase dari variabel dependen yang dapat dijelaskan oleh variabel independen. Uji $F$ dilakukan untuk mengetahui apakah variabel independen secara bersama-sama berpengaruh secara signifikan terhadap variabel dependen. Uji t dilakukan untuk mengetahui 
masing-masing variabel independen berpengaruh secara signifikan terhadap variabel dependen.

\section{Efisiensi Alokatif}

Efisiensi alokatif faktor-faktor produksi ditentukan dengan mengetahui nilai NPM/Px atau $\mathrm{Ki}$ (indeks efisiensi) dari masing-masing faktor produksi. Indeks efisiensi dari alokasi setiap faktor produksi $\left(\mathrm{k}_{\mathrm{i}}\right)$ dapat ditentukan denganrumus :

$$
\mathrm{Ki}=\text { bi } \frac{\mathrm{Y}}{\mathrm{Xi}} \cdot \frac{\mathrm{Py}}{\mathrm{Pxi}}
$$

Keterangan :

bi =elastisitas produksi faktor produksi ke-i

$\mathrm{Y}=$ produksi (output)

Py = harga output

$\mathrm{Xi}=$ jumlah penggunaan faktor produksi ke-i

Pxi $=$ harga faktor produksi ke-i

\section{HASIL ANALISIS DAN PEMBAHASAN}

\section{Estimasi Fungsi Produksi}

Estimasi fungsi produksi sorgum digunakan untuk mengetahui faktor-faktor yang mempengaruhi produksi sorgum. Produksi sorgum digunakan sebagai variabel dependen, sedangkan variabel independennya adalah luas lahan, jumlah benih, pupuk kandang, pupuk urea dan tenaga kerja.

Estimasi fungsi produksi sorgum dalam penelitian ini merupakanmodel fungsi produksi linear berganda dalam bentuk logaritma natural sehingga lebih memudahkan pandangan terhadap persamaan yang ada.Produksi sorgum adalah variabel yang dijelaskan (variabel dependen), sedangkanluas lahan, jumlah benih, pupuk kandang, pupuk urea dan tenaga kerja adalah variabel yang menjelaskan (variabel independen).

Berdasarkan Tabel 1. dapat diketahui bahwa nilai Adjusted $R^{2}$ (Koefisien determinan) yaitu sebesar 0,634 atau dengan kata lain 63,4\% variabel dependen produksi sorgum dapat dijelaskan variabel independen (luas lahan, jumlah benih, pupuk kandang, pupuk urea, dan tenaga kerja). Sisanya 36,6 \% dijelaskan oleh variabel lain diluar model.

Hasil uji $\mathrm{F}$ yaitu nilai F-hitung sebesar 11,062 dengan signifikasi 0,000 menunjukkan bahwa fungsi produksi sorgum signifikan pada tingkat kepercayaan 99\%. Hal ini berarti bahwa veriabel independen yang ada di dalam model, yaitu luas lahan, jumlah benih, pupuk kandang, pupuk urea, dan tenaga kerja secara bersamasama berpengaruh nyata terhadap produksi sorgum pada tingkat kepercayaan $99 \%$.

Hasil uji t analisis regresi produksi sorgum dengan faktor produksi yaitu luas lahan, jumlah benih, pupuk kandang, pupuk urea, dan tenaga kerja maka dapat diketahui bahwa faktor produksi yang berpengaruh secara signifikan terhadap produksi sorgum adalah luas lahan, jumlah benih, dan pupuk kandang. Sedangkan faktor produksi pupuk urea dan tenaga kerja tidak

Tabel 1. Koefisien Regresi Fungsi Produksi Sorgum Petani Sampel di Kabupaten Gunungkidul Tahun 2013

\begin{tabular}{|l|r|r|r|r|}
\hline \multicolumn{1}{|c|}{ Variabel } & Koefisien & Stand. Dev & t hitung & Sig t \\
\hline Konstanta & $5,634^{* * *}$ & 0,784 & 7,187 & 0,000 \\
\hline Ln Luas lahan & $0,448^{* *}$ & 0,174 & 2,569 & 0,017 \\
\hline Ln Jumlah benih & $0,565^{* *}$ & 0,209 & 2,701 & 0,012 \\
\hline Ln Pupuk kandang & $0,076^{* * *}$ & 0,022 & 3,485 & 0,002 \\
\hline Ln Pupuk urea & $0,021^{\mathrm{ns}}$ & 0,025 & 0,814 & 0,424 \\
\hline Ln Tenaga kerja & $0,064^{\mathrm{ns}}$ & 0,281 & 0,226 & 0,823 \\
\hline F-Hitung & & & & 11,062 \\
\hline Adj R ${ }^{2}$ & & & 0,634 \\
\hline Sig F & & & & 0,000 \\
\hline
\end{tabular}

Sumber : Analisis Data Primer 2013

Keterangan :

$* * *$ = ada beda nyatapada tingkat kesalahan $1 \%$

** = ada beda nyatapada tingkat kesalahan $5 \%$

* = ada beda nyatapada tingkat kesalahan $10 \%$

ns = tidak ada beda nyata 
berpengaruh secara signifikan. Penjelasan mengenai variabel independen yang berpengaruh maupun tidak berpengaruh secara signifikan terhadap produksi sorgum adalah sebagai berikut.

Secara statistik nilai variabel luas lahan berpengaruh signifikan terhadap produksi sorgum, nilai sig t $<0,05$. Nilai koefisien regresi luas lahan pada fungsi produksi sorgum sebesar 0,448 artinya bahwa setiap penambahan luas lahan sebesar $1 \%$ akan meningkatkan produksi sorgum sebesar $0,448 \%$. Adanya pengaruh signifikan luas lahan terhadap produksi sorgum karena lahan merupakan tempat tumbuhnya tanaman sehingga dengan bertambahnya luas lahan maka akan meningkatkan produksi.

Secara statistik nilai variabel jumlah benih berpengaruh signifikan terhadap produksi sorgum, nilai sig $\mathrm{t}<0,05$. Nilai koefisien regresi benih pada fungsi produksi sorgum sebesar 0,565 artinya setiap penambahan jumlah benih sebesar $1 \%$ akan meningkatkan produksi sorgum sebesar $0,565 \%$. Adanya pengaruh signifikan penggunaan benih terhadapproduksi sorgum karena benih merupakan bakal untuk tumbuhnya tanaman. Penggunaan benih yang tepat, pengaturan jarak tanam yang tepatakan menentukan keberhasilan produksi.

Secara statistik nilai variabel pupuk kandang berpengaruh signifikan terhadap produksi sorgum, nilai sig $\mathrm{t}<0,01$. Nilai koefisien regresi pupuk kandang pada fungsi produksi sorgum sebesar 0,076 artinya setiap penambahan jumlah pupuk kandang sebesar $1 \%$ akan meningkatkan produksi sorgum sebesar $0,076 \%$. Adanya pengaruh signifikan penggunaan pupuk kandang terhadap produksi sorgum karena pupuk kandang memiliki berbagai kandungan hara esensial yang dibutuhkan tanaman.Selain itu karakteristik lahan di daerah penelitian yang memiliki jenis tanah dengan bahan induk batu kapur, sehingga memerlukan pupuk kandang untuk meningkatkan kandungan bahan organik dalam tanah, tanahmenjadi lebih subur sehingga mendukung untuk pertumbuhan tanaman.

Secara statistik nilai variabel pupuk urea tidak memberikan pengaruh signifikan terhadap produksi sorgum. Hal ini dapat terjadi karena lahan yang digunakan untuk usahatani sorgum merupakan lahan kering pada musim kemarau sehingga kandungan bahan anorganik dari urea yang dimasukkan ke dalam tanah tidak dapat terserap maksimal, sehingga menyebabkan penambahan.

Secara statistik nilai variabel tenaga kerja tidak memberikan pengaruh signifikan terhadap produksi sorgum.Hal tersebut dapat terjadi karena tenaga kerja yang dialokasikan petani untuk memproduksi sorgum sangat kecil.Mereka melakukan penanaman kemudian pemupukan, serta pemeliharaan yang dilakukan masih kurang intensif, hal tersebut menyebabkan penggunaan tenaga kerja tidak berpengaruh signifikan terhadap produksi sorgum yang dipanen petani.

\section{Efisiensi Alokatif}

Tingkat efisiensi faktor-faktor produksi pada usahatani sorgum dapat diketahui dengan melakukan pengujian efisiensi alokatif. Uji efisiensi alokatif dapatdilakukan dengan mengetahui nilai dari indeks efisiensi alokatif atau $\mathrm{Ki}$. Indeks efisiensi alokatif (Ki) merupakan perbandingan antara nilai produk marjinal (NPMx) dengan harga faktor produksi (Px).

a. Jika nilai $\mathrm{Ki}=1$ atau nilai produk marginal (NPM) sama dengan harga input, maka penggunaan input tersebut sudah efisien.

b. Jika nilai $\mathrm{Ki}<1$ atau nilai produk marjinal (NPM) kurang dari harga input, maka penggunaan input tersebut tidak efisien.

c. Jika nilai $\mathrm{Ki}>1$ atau nilai produk marjinal (NPM) lebih dari harga input, maka penggunaan input tersebut belum efisien.

Berdasarkan Tabel 2. dapat diketahui bahwa ketiga faktor produksi yang diuji memiliki beda nyata terhadap nilai $\mathrm{Ki}=1$ atau nilai Ki dari ketiga faktor produksi yang diuji memiliki nilai $\mathrm{Ki} \neq 1$. Artinya bahwa masing-masing dari ketiga faktor produksi yang diuji yaitu luas lahan, benih dan pupuk kandang, penggunaannya belum efisien atau tidak efisien.

Penggunaan input luas lahan adalah belum efisien, hal tersebut ditunjukkan dari nilai indeks efisiensi alokatif (Ki) yang lebih dari satu (Ki < 1). Penggunaan input benih dan pupuk kandang juga belum mencapai tingkat efisien, hal tersebut ditunjukkan dari nilai indeksefisiensi alokatif (Ki) yang lebih dari satu $(\mathrm{Ki}>1)$. Penjelasan 
Tabel 2. Efisiensi Alokatif Penggunaan Input Produksi Petani Sorgum di Kabupaten Gunungkidul Tahun 2013

\begin{tabular}{|l|r|r|r|r|l|}
\hline \multicolumn{1}{|c|}{ Input } & \multicolumn{1}{c|}{ NPM } & \multicolumn{1}{c|}{ Harga } & \multicolumn{1}{c|}{ Ki } & \multicolumn{1}{c|}{ Sig t } & \multicolumn{1}{c|}{ Keterangan } \\
\hline Luas lahan & 1.585 .385 & 232.533 & 6,81 & $0,077^{*}$ & belum efisien \\
\hline Benih & 157.691 & 15.000 & 10,51 & $0,000^{* * *}$ & belum efisien \\
\hline Pupuk kandang & 104 & 50 & 2,08 & $0,014 * *$ & belum efisien \\
\hline
\end{tabular}

Sumber : Analisis Data Primer 2013

Keterangan :

*** = ada beda nyatapada tingkat kesalahan $1 \%$

** = ada beda nyatapada tingkat kesalahan $5 \%$

* = ada beda nyatapada tingkat kesalahan $10 \%$

ns $\quad$ tidak ada beda nyata

mengenai faktor-faktor produksi usahatani sorgum yang belum efisien adalah sebagai berikut.

Rasio nilai produk marjinal (NPM) dari faktor produksi luas lahan dengan nilai sewa per usahatani per musimnya lebih dari satu $(\mathrm{Ki}=6,81)$. Hal ini berarti secara alokatif penggunaan lahan oleh petani dalam usahatani sorgum belum efisien. Pemanfaatan luas lahan masih akan tetap efisien jika ditingkatkan, namun yang harus dilakukan petani dalam kegiatan usahatani sorgum adalah penggunaan masukan/input secara lebih intensif, tidak hanya sekedar memanfaatkan lahan kosong di musim kering.

Rasio nilai produk marjinal (NPM) dari faktor produksi benih dengan harga benih lebih dari satu $(\mathrm{Ki}=10,51)$. Hal ini berarti secara alokatif penggunaan benih oleh petani pada usahatani sorgum belum efisien, untuk meningkatkan produksi usahatani masih bisa diusahakan dengan menambahkan jumlah benih pada usahatani sorgum. Usahatani sorgum masih akan tetap efisien hingga peningkatan penggunaan input benih sampai dengan 135,58 $\mathrm{Kg} / \mathrm{Ha}$. Peningkatan penggunaan benih dengan pengaturan jarak tanam yang tepat akan meningkatnya produksi, hal ini akan berdampak pada penggunaan lahan yang bisa semakin efisien.

Rasio nilai produk marjinal (NPM) dari faktor produksi pupuk kandang dengan harga pupuk kandanglebih dari satu $(\mathrm{Ki}=2,08)$. Hal ini berarti secara alokatif penggunaan pupuk kandang oleh petani pada usahatani sorgum belum efisien.Usahatani sorgum masih akan tetap efisien hingga peningkatan penggunaan input pupuk kandang sampai dengan 5158,25 Kg/Ha. Pupuk kandang merupakan input yang sangat mudah diperoleh petani karena mayoritas petani memiliki hewan ternak sehingga mampu menghasilkan pupuk kandang dari hewan ternaknya. Harga untuk memperoleh pupuk kandang menjadi relatif murah.Selain itu unsur hara yang ada pada pupuk kandang sangat komplek, sehingga sangat mendukung untuk menambah kesuburan tanah.Oleh karena itu, pupuk kandang masih perlu ditingkatkan penggunaannya agar produksi pada usahatani sorgum dapat lebih efisien.

Penggunaan benih dan pupuk kandang dalam usahatani sorgum masih perlu ditingkatkan jika dibandingkan dengan anjuran dari deptan. Hal tersebut juga didukung dari hasil analisis estimasi fungsi produksi bahwa penggunaan benih dan pupuk kandang masih berada pada daerah elastisitas produksi antara 0 sampai 1 , sehingga kedua penggunaan input tersebut masih memungkinkan untuk ditingkatkan. Pemanfaatan luas lahan yang ada juga masih perlu ditingkatkan karena dari hasil analisis estimasi fungsi produksi dapat diketahui bahwa jika pemanfaatan luas lahan ditingkatkan maka akan meningkatkan produksi sorgum.

Pemanfaatan luas lahan, penggunaan input benih dan pupuk kandang juga perlu untuk ditingkatkan jika mendasarkan pada hasil analisis efisiensi alokatif. Hal tersebut dapat dipahami karena pemanfaatan luas lahan masih relatif rendah yaitu hanya 0,12 ha per usahatani, begitu pula pada penggunaan benih dan penggunaan pupuk kandang yang masih lebih rendah dari anjuran. 
Berdasarkan hasil perbandingan penggunaaan sarana produksi antara penggunaan input oleh petani dengan anjuran Deptan dan hasil analisis estimasi fungsi produksi serta hasil analisis efisiensi alokatif, maka pemanfaatan luas lahan, penggunaan benih dan penggunaan pupuk kandang masih perlu untuk ditingkatkan. Petani sorgum masih belum optimal dalam memanfaatakan input luas lahan, benih dan pupuk kandang dalam berusahatani sorgum, sehingga diperlukan pembinaan kepada petani agar mereka bersedia untuk meningkatkan pemanfaatan luas lahan secara lebih intensif agar produksi lebih maksimal, yaitu dengan meningkatkan penggunaan benih dan pupuk kandang.

Produksi sorgum petani sebesar 1,913 ton per ha masih tergolong relatif rendah, dan harga output sorgum sebesar Rp 1.700,00 per kg juga masih relatif rendah karena harga output tanaman pangan lainnya jauh lebih tinggi misal padi $( \pm \mathrm{Rp} 8.000,00$ per $\mathrm{kg}$ ). Hal tersebut dapat terjadi karena sebagian besar petani mengeluhkan pengolahan pascapanen sorgum yang masih sulit, selain itu mereka juga masih mengeluhkan pemasaran hasil sorgum yang masih sangat terbatas.Biji sorgum mayoritas pemanfaatan hanya untuk pakan burung, padahal jika merujuk pada penelitian sebelumnya, Sirappa (2003) menyebutkan bahwa sorgum dapat diolah menjadi berbagai olahan bahan pangan dalam bentuk tepung sorgum.Oleh karena itu, usaha peningkatan produksi harus didukung oleh perbaikan penanganan pascapanen dan jaringan pemasarannya.

\section{PENUTUP}

\section{Kesimpulan}

1. Produksi sorgum secara positif dipengaruhi oleh pemanfaatan luas lahan, penggunaan benih, dan penggunaan pupuk kandang.

2. Penggunaan faktor-faktor produksi dalam usahatani sorgum yaitu pemanfaatan luas lahan sebesar 0,12 per usahatani, penggunaan benih sebesar $13 \mathrm{~kg}$ per hektar dan penggunaan pupuk kandang sebesar $2.480 \mathrm{~kg}$ per hektar masih belum efisien secara alokatif.

\section{Saran}

1. Produksi sorgum bisa ditingkatkan dengan meningkatkan penggunaan benih dan pupuk kandang agar usahatani sorgum yang dilakukan petani di Kabupaten Gunungkidul bisa lebih efisien.

2. Pemanfatan luas lahan dalam berusahatani sorgum diperlukan pengelolaan yang lebih intensif dalam penggunaan input agar pemanfaatan lahan untuk usahatani sorgum pada musim kering di Kabupaten Gunungkidul bisa lebih efisien.

\section{DAFTAR PUSTAKA}

Gujarati, Damodar N.. 2006. Dasar-dasar Ekonometrika Jilid 1. Erlangga, Jakarta.

Pratisto, Arif. 2004. Cara Mudah Mengatasi Masalah Statistik dan Rancangan Percobaan dengan SPSS 12. Elex Media Komputindo, Jakarta.

Salvatore, Dominick. 2007. Scaum's Outlines: Mikroeconomic edisi Keempat. Erlangga, Jakarta.

Sirappa, M. P. 2003. Prospek Pengembangan Sorgum di Indonesia Sebagai Komoditas Alternatif untuk Pangan, Pakan dan Industri. Jurnal Litbang Pertanian 22(4).

Sukmadi, Bambang. 2010. Difusi Pemanfaatan Pupuk Organik, Pupuk Hayati dan Pestisida Hayati pada Budidaya Sorgum Manis (Sorghum bicolor L.) di Kabupaten Lampung Tengah. Balai Pengkajian Bioteknologi Deputi Bidang Teknologi Agroindustri dan Bioteknologi Badan Pengkajian dan Penenerapan Teknologi, Jakarta.

Wirartha, I Made. 2006. Metodologi Penelitian Sosial Ekonomi. Andi, Yogyakarta. 